\title{
Pleomorphic Adenoma in a Young Female: Case Report
}

\author{
Adenoma Pleomórfico en una Mujer Joven: Reporte de Caso
}

\author{
Wilfredo Alejandro González-Arriagada'; Sebastián Wilson²; \\ José Bastías ${ }^{2}$; Enrique Steffens ${ }^{2} \&$ Ricardo Moreno ${ }^{1}$
}

GONZÁLEZ-ARRIAGADA, W. A.; WILSON, S.; BASTÍAS, J.; STEFFENS, E. \& MORENO, R. Pleomorphic adenoma in a young female: Case report. Int. J. Odontostomat., 11(4):475-479, 2017.

\begin{abstract}
Pleomorphic adenoma (PA) is the most common benign salivary gland neoplasm and it is frequently diagnosed in the third and fourth decade with predilection for women. PA is the most common benign lesion of minor salivary glands in children and adolescents, being the palate one of the most frequently affected site of minor salivary glands. Herein, we present a case report of a PA of the hard palate diagnosed in a 15-year-old female and a review of the Englishliterature of the reported cases of PA in children and adolescents in the hard palate.
\end{abstract}

KEY WORDS: mouth, hemangioma, vascular malformationboca, hemangioma, malformación vascular.

\section{INTRODUCTION}

Pleomorphic adenoma (PA) is the most common benign salivary gland neoplasm and it accounts for $60 \%$ of these. It is frequently diagnosed in the third and fourth decade and has a predilection for women. In minor salivary glands, it generally occurs in the hard palate and in the upper lip. PA is the most common benign salivary gland tumor in children and mucoepidermoid carcinoma is the most frequent malignancy. Fewer than $5 \%$ of all primary salivary gland neoplasms occur in children, in the first decade of life, usually the first 2 years of life, with a preponderance of benign neoplasms (Seifert et al., 1986; Callender et al., 1992; Luna et al., 1991; Jorge et al., 2002; Mehta \& Willging, 2006).

PA typically occurs as a firm, painless, and slow growing mass. In minor salivary glands, the palate is the most frequent location, and appears as a lobulated mass, usually covered by normal overlying mucosa. Histologically, it is characterized by the presence of epithelial and mesenchymal elements, giving rise to ductal structures, intermingled with a stroma with myxoid, hyaline, cartilaginous, and osseous change. This tumor is usually encapsulated, but extensions into adjacent tissues may be observed (Seifert et al.; Callender et al.; Luna et al.; Jorge et al.; Mehta \& Willging).
Herein, we present a case report of a PA of the hard palate diagnosed in a 15-years-old female and a review of the English-literature of the reported cases of PA in children and adolescents with hard palate.

\section{CASE REPORT}

A 15 year-old female patient was referred to the Oral Health Diagnostic Service with chief complaint of painless swelling for a period of six months, in the right posterior hard palate close to the first molar. Imaging exams did not show underlying bone involvement. The medical history was not contributory.

Clinical examination revealed a single swelling, enlarging the hard palate to the midline. The lesion is fluctuated slightly over the bone and showed a smooth surface with a color similar to the oral mucosa with telangiectasia-like appearance at the center (Fig. 1).

An incisional biopsy was performed under local anesthesia, without post-surgery complications. Macroscopically, was observed a pyramidal shaped, firm and smooth brownish-white specimen of $10.5 \times 7$

\footnotetext{
${ }^{1}$ Patología y Diagnóstico Oral, Facultad de Odontología, Universidad de Valparaíso, Valparaíso, Chile.

${ }^{2}$ Alumno de pregrado, Facultad de Odontología, Universidad de Valparaíso, Valparaíso, Chile.
} 
x $6 \mathrm{~mm}$ of size. The histopathological examination noted a solid lesion covered by a orthokeratinized pluriestratified epithelium, surrounded by a fibrous capsule (Fig. 2A). The tumor mass showed solid areas intermingled with ductal-like areas, between variable amounts of extracellular matrix and some fibro vascular septa (Fig. 2B). The cells showed cuboidal, plasmacytoid, clear and epithelioid morphology (Fig. $2 \mathrm{C})$. In the microscopic sample were observed microcysts with eosinophilic matrix inside, looser areas of adipose and chondroid appearance, and cellular diversity, but without presence of atypia or mitosis (Fig. 2D). There was no evidence of malignancy. The diagnosis was Pleomorphic Adenoma and the patient was referred to the Maxillofacial Service of the Public Hospital. The lesion was completely removed and no recurrence was observed in two years of follow-up.

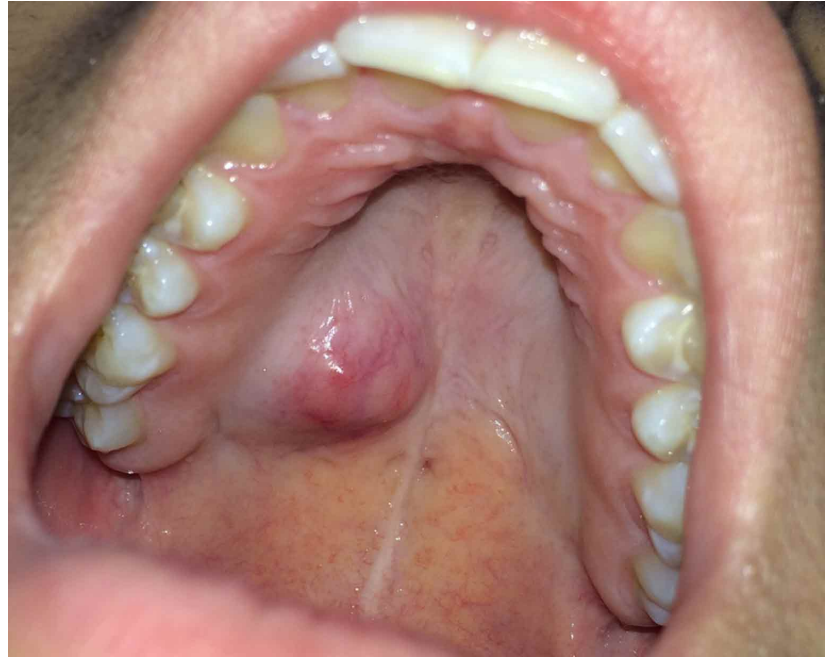

Fig. 1. Photograph showing the clinical appearance of the lesion.

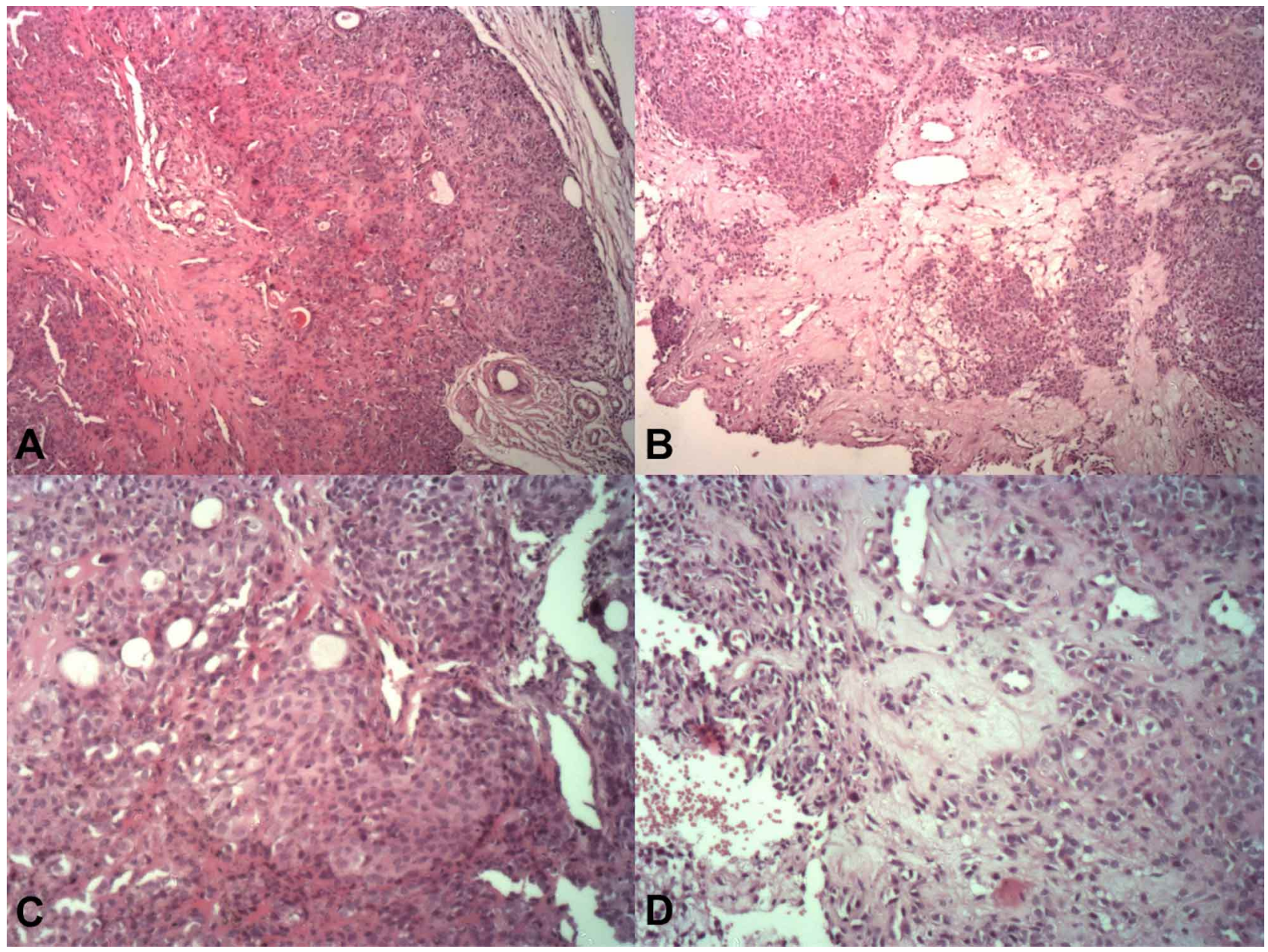

Fig. 2. Microscopic photographs showing the main features of the lesion. A) A solid lesion with hypercellular areas surrounding a fibrous central area. Note the fibrous capsule (HE, low magnification, 50X). B) Variable amount of extracellular matrix intermingled with the cellular areas (HE, low magnification, 50X). C) Some areas shows a duct-like conformation with epithelioid and plamacytoid morphology of the cells (HE, high magnification, 100X). D) Clear cell areas showing the myoepithalial component of the lesion (HE, high magnification, 100X). 
Table I. List of reported cases of Pleomorphic Adenoma in children and adolescents.

\begin{tabular}{|c|c|c|c|}
\hline Author & Sex & Age (years) & Site \\
\hline Byars et al., 1957 & Female & 9 & Hard palate \\
\hline Byars et al., 1957 & Female & 7 & Hard palate \\
\hline Crawford-Guempsey, 1967 & Female & 8 & Left hard and soft palate \\
\hline Galich, 1969 & Female & 12 & Hard and soft palate \\
\hline Buehrle \& Friedberg, 1972 & Female & 13 & Right hard and soft palate \\
\hline Budnick, 1982 & Female & 12 & Hard and soft palate \\
\hline Budnick, 1982 & Female & 12 & Hard palate \\
\hline Mcllveen et al., 1987 & Female & 7 & Hard palate \\
\hline Lack and Upton, 1988 & Male & 10 & Soft palate \\
\hline Fonseca et al., 1991 & Female & 16 & Soft palate \\
\hline Fonseca et al., 1991 & Femae & 8 & Soft palate \\
\hline Austin \& Crockett, 1992 & Female & 10 & Hard palate \\
\hline Noghreyan et al., 1995 & Female & 8 & Hard palate \\
\hline Lopez-Cedrun et al., 1996 & Male & 16 & Hard palate \\
\hline de Courten et al., 1996 & Female & 10 & Hard palate \\
\hline Chen et al., 1998 & Female & 15 & Right hard palate \\
\hline Shaaban et al., 2001 & Male & 9 & Hard palate \\
\hline Jorge et al., 2002 & Male & 11 & Soft palate \\
\hline Jorge et al., 2002 & Female & 17 & Hard palate \\
\hline Daniels et al., 2007 & Male & 5 & Left hard palate \\
\hline Daniels et al., 2007 & Male & 16 & Left hard palate \\
\hline Dhanuthai et al., 2009 & Female & 13 & Left hard palate \\
\hline Arcuri et al., 2011 & Male & 11 & Right hard palate \\
\hline Ritwik \& Brannon, 2012 & Female & 15 & Right hard palate \\
\hline Ritwik \& Brannon, 2012 & Female & 17 & Left hard palate \\
\hline Ritwik \& Brannon, 2012 & Male & 12 & Hard palate \\
\hline Ritwik \& Brannon, 2012 & Female & 15 & Soft palate \\
\hline Ritwik \& Brannon, 2012 & Male & 12 & Soft palate \\
\hline Thangaswamy et al., 2012 & Male & 19 & Hard palate \\
\hline Zainab, 2013 & Female & 13 & Right hard Palate \\
\hline Krishna, 2013 & Female & 14 & Hard palate \\
\hline Maclsaac et al., 2013 & Female & 7 & Right hard palate \\
\hline Bovino et al., 2013 & Male & 12 & Hard palate \\
\hline Hughes et al., 2015 & Female & ND & Soft Palate \\
\hline Swain et al., 2016 & Male & 13 & Left soft palate \\
\hline Current case & Female & 15 & Right hard palate \\
\hline
\end{tabular}

\section{DISCUSSION}

Salivary gland tumors are uncommon in the first decades of life. The majority of these tumors are benign, but in minor salivary glands the incidence of malignant tumors is approximately $50 \%$ of the reported cases. In children, major salivary glands are more affected by salivary gland tumors than minor salivary glands. PA is the most common benign lesion of minor salivary glands in children and adolescents, being the palate one of the most frequently affected site of minor salivary glands. To the best of our knowledge, 36 cases of palatal PA were reported in the first and second decade of life (Table I). The age range was 5 to 19 years-old, with a mean age of 12.4 years-old. The incidence is higher in the second decade, with $25.7 \%$ of the tumors occurring in patients younger than 10 years (Byars et al., 1957; Crawford \& Guernsey, 1967; Galich, 1969; Buehrle \& Friedberg, 1972; Budnick, 1982; Mcllveen et al., 1987; Lack \& Upton, 1988; Fonseca et al., 1991; Austin \& Crockett, 1992; Noghreyan et al., 1995; Lopez-Cedrún et al., 1996; de Courten et al., 1996; Chen et al., 1998; Shaaban et al., 2001; Jorge et al.; Daniels et al., 2007; Dhanuthai et al., 2009; Arcuri et al., 2011; Ritwik \& Brannon, 2012; Thangaswamy et al., 2012; Bovino et al., 2013; 
Maclsaac et al., 2013; Pramod Krishna, 2013; Zainab, 2013; Hughes et al., 2015; Swain et al., 2016).

Byars et al., reported the first 2 cases of palatal PA in children aged 7 years and 9 years (Byars et al.). The current case occurred in a young girl, and reports in the English literature revealed a female sex predilection (3:1). The majority was described as painless and as firm sub-mucosal masses or nodules (Byars et al.; Crawford \& Guernsey; Galich; Buehrle \& Friedberg; Budnick; Mcllveen et al.; Lack \& Upton; Fonseca et al.; Austin \& Crockett; Noghreyan et al.; Lopez-Cedrún et al.; de Courten et al.; Chen et al.; Shaaban et al.; Jorge et al.; Daniels et al.; Dhanuthai et al.; Arcuri et al.; Ritwik \& Brannon; Thangaswamy et al.; Bovino et al.; Maclsaac et al.; Pramod Krishna; Zainab; Hughes et al.; Swain et al.). Six of these cases caused underlying-bone involvement, described as pressure erosion, smooth depression, or reabsorption (Chen et al.; Dhanuthai et al.; Arcuri et al.; Ritwik \& Brannon); and one of these cases perforated the palatal bone, extending into nasal cavity (Arcuri et al.). The time of evolution is usually fast-growing, being faster than in adult patients (Chen et al.).

Biopsy is necessary to diagnose asymptomatic palatal swelling of firm consistency. Histopathologically, PA is composed of a wide spectrum of epithelial and mesenchymal tissue derived from cells with ductal and myoepithelial features with a rich stroma, often with myxomatous appearance (Chen et al.; Jorge et al.; Dhanuthai et al.; Arcuri et al.; Ritwik \& Brannon), and some cases with the presence of cartilaginous or osteoid formation inside the tumor (Shaaban et al.). The treatment of PA is the same in adults, and the recurrence of PAs in minor salivary glands of children was rarely reported, but we do not know if these recurrences were associated with the tumor behavior or surgical problems (Daniels et al.). Recurrence on the palate could be a serious complication, because is necessary greater margins of the surgery.

In conclusion, PA rarely occurs before the second decade of life, but is the most common salivary gland neoplasm in children and adolescents, with a female predilection, and should be considered in the differential diagnosis of young patients with swellings in the palate. This case report will contribute to a better characterization of PA in children and adolescents, determining a true sex predilection and age of distribution with a higher number of reported cases.
GONZÁLEZ-ARRIAGADA, W. A.; WILSON, S.; BASTÍAS, J.; STEFFENS, E. \& MORENO, R. Adenoma pleomórfico en una mujer joven: Reporte de caso. Int. J. Odontostomat., 11(4):475-479, 2017.

RESUMEN: El adenoma pleomórfico (AP) es la neoplasia benigna más común de las glándulas salivales y se diagnostica frecuentemente en la tercera y cuarta década con predilección por las mujeres. El AP es la lesión benigna más común de las glándulas salivales menores en niños y adolescentes, siendo el paladar uno de los sitios más frecuentemente afectados de las glándulas salivales menores. En este trabajo se presenta un relato de caso de un AP de paladar duro diagnosticado en una mujer de 15 años de edad y una revisión de la literatura en inglés de los casos reportados de AP en niños y adolescentes en paladar duro.

PALABRAS CLAVE: boca, hemangioma, malformación vascular.

\section{REFERENCES}

Arcuri, F.; Grivetto, F.; Poglio, G.; Brucoli, M. \& Benech, A. Simultaneous palatal pleomorphic adenoma and mandibular keratocystic odontogenic tumor in a pediatric patient. J. Craniofac. Surg., 22(6):2347-50, 2011.

Austin, J. R. \& Crockett, D. M. Pleomorphic adenoma of the palate in a child. Head Neck, 14(1):58-61, 1992.

Bovino, B. F.; Sohn, A. \& Winston, D. Pleomorphic adenoma of the palate in a child. N. Y. State Dent. J., 79(4):44-7, 2013.

Budnick, S. D. Minor-salivary-gland tumors in children. ASDC J. Dent. Child., 49:44-7, 1982.

Buehrle, R. \& Friedberg, J. Mixed salivary gland tumor of the palate in a child. Arch. Otolaryngol., 96(2):163-4, 1972.

Byars, L. T.; Ackerman, L. V. \& Peacock, E. Tumors of salivary gland origin in children: a clinical pathologic appraisal of 24 cases. Ann. Surg., 146(1):40-51, 1957.

Callender, D. L.; Frankenthaler, R. A.; Luna, M. A.; Lee, S. S. \& Goepfert, H. Salivary gland neoplasms in children. Arch. Otolaryngol. Head Neck Surg., 118(5):472-6, 1992.

Chen, Y. K.; Lin, L. M.; Lin, C. C. \& Yan, Y. H. Palatal pleomorphic adenoma in a child with osteoid formation: report of case. ASDC J. Dent. Child., 65(3):209-11, 1998.

Crawford, W. H. Jr. \& Guernsey, L. H. Pleomorphic adenoma of the palate. Report of a case. Oral Surg. Oral Med. Oral Pathol. Oral Radiol., 23(1):116-26, 1967.

Daniels, J. S.; Ali, I.; Al Bakri, I. M. \& Sumangala, B. Pleomorphic adenoma of the palate in children and adolescents: a report of 2 cases and review of the literature. J. Oral Maxillofac. Surg., 65(3):541-9, 2007.

de Courten, A.; Lombardi, T. \& Samson, J. Pleomorphic adenoma of the palate in a child: 9-year follow-up. Int. J. Oral Maxillofac. Surg., 25(4):293-5, 1996. 
Dhanuthai, K.; Sappayatosok, K. \& Kongin, K. Pleomorphic adenoma of the palate in a child: a case report. Med. Oral Patol. Oral Cir. Bucal, 14(2):E73-5, 2009.

Fonseca, I.; Martins, A. G. \& Soares, J. Epithelial salivary gland tumors of children and adolescents in southern Portugal. A clinicopathologic study of twenty-four cases. Oral Surg. Oral Med. Oral Pathol., 72(6):696-701, 1991.

Galich, R. Salivary gland neoplasms in childhood. Arch. Otolaryngol., 89(6):878-82, 1969.

Hughes, A. L.; Yang, E. \& Vargas, S. O. A pediatric soft palate mass. Pleomorphic adenoma. JAMA Otolaryngol. Head Neck Surg., 141(4):391-2, 2015.

Jorge, J.; Pires, F. R.; Alves, F. A.; Perez, D. E.; Kowalski, L. P.; Lopes, M. A. \& Almeila, O. P. Juvenile intraoral pleomorphic adenoma: report of five cases and review of the literature. Int. J. Oral Maxillofac. Surg., 31(3):273-5, 2002.

Lack, E. E. \& Upton, M. P. Histopathologic review of salivary gland tumors in childhood. Arch. Otolaryngol. Head Neck Surg., 114(8):898-906, 1988.

Lopez-Cedrún, J. L.; Gonzalez-Landa, G. \& Birichinaga, B. Pleomorphic adenoma of the palate in children: report of a case. Int. J. Oral Maxillofac. Surg., 25(3):206-7, 1996.

Luna, M. A.; Batsakis, J. G. \& el-Naggar, A. K. Salivary gland tumors in children. Ann. Otol. Rhinol. Laryngol., 100(10):869-71, 1991.

Maclsaac, Z. M.; Naran, S. \& Losee, J. E. Pleomorphic adenoma: a rare intraoral pediatric tumor. J. Craniofac. Surg., 24(2):669-71, 2013.

Mcllveen, L. P.; Sharp, H. K. \& Schuman, N. J. Pleomorphic adenoma of a minor salivary gland: report of a case. Quintessence Int., 18(3):211-3, 1987.

Mehta, D. \& Willging, J. P. Pediatric salivary gland lesions. Semin. Pediatr. Surg., 15(2):76-84, 2006.

Noghreyan, A.; Gatot, A.; Maor, E. \& Fliss, D. M. Palatal pleomorphic adenoma in a child. J. Laryngol. Otol., 109(4):343-5, 1995.

Pramod Krishna, B. Pleomorphic adenoma of minor salivary gland in a 14 year old child. J. Maxillofac. Oral Surg., 12:228-31, 2013.

Ritwik, P. \& Brannon, R. B. A clinical analysis of nine new pediatric and adolescent cases of benign minor salivary gland neoplasms and a review of the literature. J. Med. Case Rep., 6:287, 2012.

Seifert, G.; Okabe, H. \& Caselitz, J. Epithelial salivary gland tumors in children and adolescents. Analysis of 80 cases (Salivary Gland Register 1965-1984). ORL J. Otorhinolaryngol. Relat. Spec., 48(3):137-49, 1986.

Shaaban, H.; Bruce, J. \& Davenport, P. J. Recurrent pleomorphic adenoma of the palate in a child. $\mathrm{Br}$. J. Plast. Surg., 54(3):245-7, 2001.

Swain, S. K.; Das, A. \& Sahu, M. C. An unusual presentation of pleomorphic adenoma of the soft palate in a 13-yearold boy - A case report. Pediatr. Pol., 91(3):265-8, 2016.

Thangaswamy, V.; Sivakumar, A.; Sivakumar, A.; Sivaraj; Pugazhendi, S. K. \& Thambiah, L. Pleomorphic adenoma in an adolescent. J. Pharm. Bioallied Sci., 4:S435-6, 2012.

Zainab, H. Juvenile pleomorphic adenoma: A case report. Int. J. Dent. Sci. Res., 1:70-2, 2013.
Corresponding author:

Wilfredo González Arriagada

Facultad de Odontología

Universidad de Valparaíso

Subida Carvallo 211

Playa Ancha

Valparaíso

CHILE

E-mail: wilfredo.gonzalez@uv.cl

Received: 27-09-2016

Accepted. 26-07-2017 